uct of obtaining valuable technical skills. Poor and minority students may or may not have enough role models to emulate; therefore teachers need to provide real and vicatious examples of people who work with technology.

You can help minority students by getting them to buy into the wonderful world of technology. Do an entire thematic lesson on technology? Look at earlier forms of technology to present day inventions. Have students brainstorm about the technical inven. tions in their communities and then create a timeline. Students can hang pictures of the technical inventions on the timeline. This can lead to dis. cussions about the inventions and in. ventors (many of whom were African Americans and Latinos). This thematic unit empowers students as they see how their people have been inventors of technologies and how they also have the capability of being producers of technology.

With minority students you must connect your pedagogy to something that they can relate to within their world; this is "culturally responsive pedagogy" (Gay, 2000, p. 111). Show minority students that you value their language, culture, ethnic identity, com- munities, and history, and you are half way to achieving your learning goals.

\section{CONCLUSION}

Minority students need to be provided with many opportunities to use technology at school, the library or at home. However the basics must begin at school because many children do not have access to computers and other contemporary forms of technology.

The consistent use of tech talk empowers minority students and helps them to be competitive participants in this technologically driven society. Use tech talk as a daily recipe to linguistic, cultural, ethnic and academic empowerment for all students.

\section{REFERENCES}

Delpit, L. D. (1993). The politics of teaching literate discourses, in: Perry, T. \& Fraser, J. W. (Eds.) Freedom's Plow: Teaching in the multicultural classroom, pp. 285-295, New York: Routledge.

Gay, G. (2000). Culturally Responsive Teaching, New York: Teachers College Press.

Kinzie, M. B. (1990). Requirements and benefits of effective interactive instruction: Learner control, selfregulation and continuing motivation, Educational Technology Research and Development, 38, pp. 5-21.

Roblyer, M. D. \& Edwards, J. (2000). Integrating educational technology into teaching, Upper Saddle River, NJ: Prentice Hall.

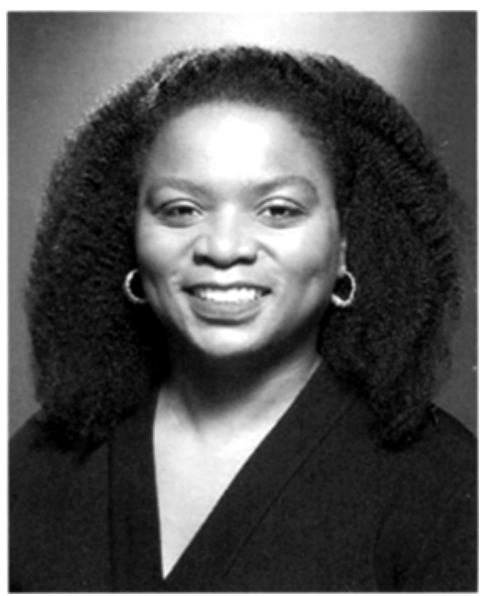

Dr. Patricio A. Young is an Assistant Professor in the Department of Elementary and Bilingual Education at Californio State University Fullerton. She teaches courses in cultural pluralism, instructional technology, and a variety of courses at both the credential and graduate levels in education.

\title{
Other Awards from the 2001 AECT Convention in Atlanta
}

Marcy Driscoll gave the following special Presidential awards:

K.J. Saville "...for outstanding service in coordinating arrangements for AECT's Summer Leadership Institute."

Robert Harrell "...for dedicated service as an ad hoc advisor to the AECT President and Executive Director."

Deborah Lowther "...for dedicated service as convention chair of the February 2000 Annual AECT Convention."

Marcie Bober "...for dedicated service as host city chair and volunteer coordinator of the November 2000 Annual AECT convention."

Nathan Lowell "...in recognition of your leadership and effort to establish a graduate student organization within AECT."

AECT gave David Jonassen a Presidential Special Recognition Award for his contribution to the revision and online availability of the "Handbook of Research for Educational Communications and Technology."

Jackie Hill received an "AECT Special Service Award.”

The Editors of TechTrends (Don Descy, Patricia Stockland, Steve Hackbarth, Leslie Hall, Terry Holcomb, Gary Powell, Laurie Quinlan, Michael Simonson, Esther Sinofsky, Charles Stoddard, David Tiedemann, Robert Wiseman, Jane Zahner) received the "2001 Annual Achievement Award" 